\title{
THE EARLY MESSIANIC ‘AFTERLIFE’ OF THE TREE METAPHOR IN EZEKIEL 17:22-24
}

\author{
William R. Osborne
}

\begin{abstract}
Summary
This article discusses the royal associations of tree imagery in the ancient Near East before examining four early messianic interpretations of the tree symbolism in Ezekiel 17:22-24, namely those of 4QEzekiel ${ }^{a}$, the Septuagint, Targum Ezekiel, and The Shepherd of Hermas.
\end{abstract}

\section{Introduction}

Recent scholarship related to Ezekiel has focused on the reception history of the book, yielding several studies that highlight the ongoing influence of this prophetic visionary of the Babylonian exile. ${ }^{1}$ While studies on reception history do serve the modern interpreter by providing a hermeneutical context for their own reading within more recent history, the goal of this work is to examine some of the earliest translations and interpretations of Ezekiel 17:22-24 in an effort to better understand the text. $^{2}$ These three verses conclude the

1 Paul M. Joyce and Andrew Mein, eds., After Ezekiel: Essays on the Reception of a Difficult Prophet (LHB/OTS 535; New York: T\&T Clark International, 2011); Paul M. Joyce, 'After Ezekiel: Ezekiel in Tradition' in Ezekiel: A Commentary (New York: T\&T Clark International, 2007); 'Ezekiel' in The Oxford Handbook to the Reception History of the Bible, ed. M. Lieb, E. Mason, and J. Roberts (Oxford: Oxford University Press, 2011); Henk Jan De Jong and Johannes Tromp, eds., The Book of Ezekiel and Its Influence (Burlington, VT: Ashgate, 2007); A. R. Christman, 'What Did Ezekiel See?': Christian Exegesis of Ezekiel's Vision of the Chariot from Irenaeus to Gregory the Great (The Bible in Ancient Christianity 4; Leiden: Brill, 2005); K. Stevenson and M. Glerup, eds., Ezekiel, Daniel (Ancient Christian Commentary on Scripture, Old Testament 13; Downers Grove, IL: InterVarsity, 2008).

2 'The ambiguity of most of the terms in the fable allows such a misconstruing and justifies it being entitled a riddle as well as a fable', Moshe Greenberg, Ezekiel 1-20 (Anchor Bible 22; Garden City, NY: Doubleday, 1983): 321. 
metaphorical parable of Ezekiel 17 and speak to Israel's future in terms of tree symbolism. However, tree symbolism is used in the Old Testament and Second Temple period to represent diverse concepts such as the Garden of Eden, the Tree of Life, the natural world, political leaders, luxuriant living, laying siege to a town, and messianic prophecy. To add to the challenge, such symbolism seems to have been so widely understood among ancient audiences that its use hardly warranted explanation or attention. This article seeks to address these challenges by (1) briefly discussing the political significance of tree symbolism in the ancient Near East, (2) providing a reading and commentary of the Masoretic Text (MT) of Ezekiel 17:22-24, (3) focusing on the early 'afterlife' of the tree metaphor discovered in allusions and translations in 4QPseudo-Ezekiel ${ }^{\mathrm{a}}$ (4Q385 frag. 2), the Septuagint (LXX), Targum Ezekiel, and The Shepherd of Hermas (SH), and (4) concluding that these texts give evidence of early individual and messianic interpretations of Ezekiel 17:22-24. The texts being studied are presented in diachronic order and provide some of the earliest interpretations of the passage. ${ }^{3}$

\section{Trees and Kings in the Ancient World}

When encountering tree symbolism in prophetic and apocalyptic literature, the Tree of Life symbol has served as the interpretative key for many. This is also the case for the tree metaphor in Ezekiel 17:22$24 .{ }^{4}$ While the Tree of Life image is significant, and at times quite evident, one of the characteristics of apocalyptic/prophetic literature is that it frequently defies systematic symbolic correlations. ${ }^{5}$

3 The Latin Vulgate reflects the MT, and the Peshitta deviates from the MT at one location and will be addressed alongside the LXX.

4 Alison Jack, 'An Arboreal Sign of the End-Time (4Q385 2)', Journal of Jewish Studies 47 (1996): 337-44; M. Philonenko, 'Un arbre se courbera et se redressera (4Q385 2 9-10)', Revue d'histoire et de philosophie religieuses 73 (1994): 401-404. Walther Zimmerli, Ezekiel 1: A Commentary on the Book of the Prophet Ezekiel, Chapters 1-24 (tr. by R. E. Clements; Hermeneia; Philadelphia, PA: Fortress,1979): 367; Margret S. Odell, Ezekiel (Smyth \& Helwys Bible Commentary; Macon, GA: Smyth \& Helwys, 2005): 212; Johan Lust, 'And I Shall Hang Him on a Lofty Mountain: Ezek. 17:22-24 and Messianism in the Septuagint' in IX Congress of the International Organization for Septuagint and Cognate Studies, ed. B. A. Taylor (Society of Biblical Literature Septuagint and Cognate Studies Series 45; Atlanta, GA: Scholars, 1997): 235.

5 Robert R. Wilson, 'From Prophecy to Apocalyptic: Reflections on the Shape of Israelite Religion', Semeia 21 (1980): 86. 
Consequently, studies may easily overlook the significance of the treeking relationship exhibited in the Neo-Assyrian and Neo-Babylonian period, which is then employed by Ezekiel. ${ }^{6}$ Geo Widengren has ably demonstrated the intimate symbolic relationship between the king and the 'cosmic tree' in the ancient world in his work The King and The Tree of Life in Ancient Near Eastern Religion. ${ }^{7}$ According to Widengren, the king is not only the keeper of the tree and the possessor of the tree, he $i$ s the tree. Widengren states: 'It is above all necessary to stress that both Tree and Water of Life as symbols of the king are met in the same glorification of Messiah. ${ }^{8}$ Simo Parpola in his influential study 'The Assyrian Tree of Life: Tracing the Origins of Jewish Monotheism and Greek Philosophy', comes to a similar conclusion regarding this union between the tree and the king. He comments on the sacred tree reliefs at Nimrud: 'Basically, it symbolised the divine world order maintained by the Assyrian king, but inversely it could also be projected upon the king to portray him as the Perfect Man.' Therefore, one would not be surprised to find cosmic tree language closely connected to royal symbolism and prophecy. Indeed Nicolas Wyatt comments on tree imagery stating: 'Two main themes occur widely: the tree is both an axis mundi ... that is, the central pillar of the universe ... and an allomorph (alternative form) of the (androgynous) Primal Man.' ${ }^{10}$ Given this prevalent association between the tree and

\footnotetext{
6 Simo Parpola writes, ' $[\mathrm{I}] \mathrm{t}$ was observed some time ago that in some reliefs the king takes the place of the Tree between the winged genies. Whatever the precise implications of this fact, it is evident that in such scenes the king is portrayed as the human personification of the Tree' in 'The Assyrian Tree of Life: Tracing the Origins of Jewish Monotheism and Greek Philosophy', JNES 52 (1993): 167. See also Barbara Nevling Porter, 'Sacred Trees, Date Palms, and the Royal Persona of Ashurnasirpal II', JNES 52 (1993): 129-39; Geo Widengren, The King and the Tree of Life in Ancient Near Eastern Religion (King and Saviour IV; Uppsala Universitets Arsskrift 1951:4; Uppsala: A.-B. Lundequistska Bokhandeln, 1951); Odell, Ezekiel, 212.

7 Geo Widengren, The King and the Tree of Life, 55. Unfortunately Widengren does not differentiate the 'cosmic tree', or 'sacred tree', from the Tree of Life. However, his observations remain helpful.

8 Geo Widengren, The King and the Tree of Life, 55. Despite addressing numerous apocryphal and Old Testament passages, Widengren fails to mention Ezek. 17:22-24 in his study.

9 Simo Parpola, 'The Assyrian Tree of Life', 168. See also Porter, 'Sacred Trees, Date Palms', 129-39.

10 Nicolas Wyatt, Space and Time in the Religious Life of the Near East (Biblical Seminar 85; Sheffield: Sheffield Academic, 2001): 166.
} 
the king in the 'cognitive cultural environment' of the ancient world, ${ }^{11}$ is this political relationship observable in the early history of interpretation of Ezekiel 17:22-24?

Before continuing it must be stated that the writers of the documents examined in this study lived in a context rather removed from the NeoAssyrian and Neo-Babylonian period. Why, then, should one look for the presence of an earlier motif in their work? First, their context is not so far removed when one considers the vast influence of Neo-Assyrian and Neo-Babylonian culture in the ancient world. Second, the continued presence of tree imagery as a symbol of national identity in early Judaism (Maccabean period, ca. 167-63 BC) seems to indicate an ongoing association with the symbolised tree and the political powers of the day. ${ }^{12}$ Parpola also recognises the long lasting influence of the Assyrian image within Judaism by arguing for a direct and intentional connection between the ancient sacred tree and the Sefirotic Tree of medieval Kabbalistic thought. ${ }^{13}$ Therefore, it seems justifiable to examine the reception history of Ezekiel 17:22-24 alongside the ancient concept of a tree-king royal ideology.

\section{Ezekiel 17:22-24: Masoretic Text}

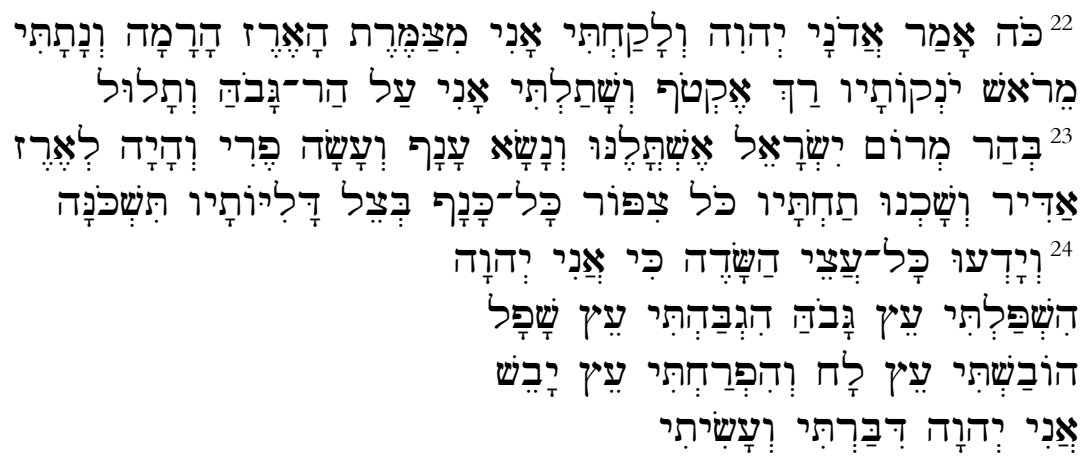

11 John H. Walton, Ancient Near Eastern Thought and Old Testament: Introducing the Conceptual World of the Hebrew Bible (Grand Rapids, MI: Baker, 2006): 21-29.

12 See James F. Strange, 'The Art and Archaeology of Ancient Judaism' in Judaism in Late Antiquity, vol. 1, ed. Jacob Neusner (Boston: Brill Academic, 2001): 106-107.

13 Parpola, 'The Assyrian Tree of Life', 169-92. Cf. Barbara Nevling Porter, Trees, Kings, and Politics: Studies in Assyrian Iconography (Orbis Biblicus et Orientalis 197; Göttingen: Vandenhoeck \& Ruprecht, 2003): 27-29. 
22 Thus says the Lord YHWH, 'I myself shall take [a shoot] from the lofty top of the cedar and I will place it. I shall pluck from its top a tender sapling and I shall plant [it] myself on a high and lofty mountain. ${ }^{23}$ On the mountain height of Israel, I shall plant it and it shall raise up branches and produce fruit and it shall be a magnificent cedar and every kind of bird shall dwell under it and every kind of winged creature shall dwell in the shadow of its branches.

${ }^{24}$ And all the trees of the field shall know that I am YHWH;

I bring low a lofty tree, I exalt a low tree

I dry up the fresh tree and I bring into bloom the dry tree

I am YHWH, I have spoken and I will do [it]. ${ }^{14}$

Examining Ezekiel 17:22-24 in its context reveals that chapter 17 is comprised of a parable (משל) given to the people of Israel concerning the nation's political maneuvrings at the hand of Zedekiah between Nebuchadnezzar of Babylon and Pharaoh Psammetichus in Egypt between 594 and $588 \mathrm{BC}^{15}$ In the parable, Jerusalem is likened to the awe-inspiring forests of Lebanon, ${ }^{16}$ and Nebuchadnezzar is portrayed as an extravagant eagle that takes Jehoiachin, the 'top' (צמרת) of a 'cedar' (ארז), away to Babylon and sows a local seed in its placeZedekiah. ${ }^{17}$ This seed grows by 'abundant waters' (מים רבים), and the vine - not the cedar-spreads out its branches (פארות). However, the vine quickly redirects its roots toward a second eagle representing Egypt. Zedekiah acts in defiance against the covenant he entered into with Nebuchadnezzar (2 Chr. 36:11-12), who placed him under an oath in order that 'the kingdom might be low and not lift itself up (התנשהא)' (Ezek. 17:13-14). Interestingly, Yahweh views Zedekiah's rebellion toward Babylon as rebellion toward himself, and Zedekiah's pride and covenant disloyalty ultimately result in judgement (Ezek. 17:20). Whereas verses 12-19 offer an interpretation of the metaphor, no more information is provided about Jehoiachin, the cedar top, or his future. The topic of the cedar sapling does not re-enter the parable until the last three verses. Verse 21 concludes with the same divine resolution as

14 Unless otherwise noted, all translations are original to the author.

15 Greenberg, Ezekiel 1-20, 12-13.

16 Note the description of the cedar forests from Tablet V of the Epic of Gilgamesh, 'The cedars raise aloft their luxuriance. Good is their shade, full of delight. There is cover in their brushwood, cover in their [...].' See 'The Epic of Gilgamesh' (tr. by E. A. Speiser in ANET [3rd edn; Princeton, NJ: Princeton University Press, 1969]): 82.

17 It was common for ANE kings to gather trees from conquered lands and plant them in their illustrious gardens as a sign of dominance. See Bernard Lang, Kein Aufstand in Jerusalem: Die Politik des Propheten Ezechiel (Stuttgarter Biblische Beiträge; Stuttgart: Katholisches Bibelwerk, 1978): 61. 
in verse 24, 'I am YHWH; I have spoken.' While this repetition marks verses $22-24$ as a distinct literary unit within the chapter, there is no reason to deny their original inclusion in chapter $17 .{ }^{18}$

In Ezekiel 17:22-24 Yahweh is symbolised as a second eagle and performs the same action of the first eagle (Nebuchadnezzar) and plants his own sapling that will grow into a magnificent (אדיר) cedar 'on the mountain height of Israel' (בהר מרום ישראל). As G. A. Cooke writes, '[W] hat had been an act of violence will be turned into an act of grace.' אני ('myself') and multiple first person verbal constructions communicates clearly that this future restoration will be solely the Lord's doing. However, this presents two major questions which are quite germane to the present discussion. What is it precisely that YHWH will do? And, how does the symbolism of the tree factor into this restorative vision?

In answer to these questions, four major possibilities arise: (1) The reader is to understand this magnificent cedar as a contemporary, historical prediction of the longed-for return of Jehoiachin to the throne of Judah. ${ }^{20}$ (2) Looking to verse 23 and the birds resting beneath its branches, the tree imagery is an allusion to the Tree of Life symbol often associated with Ezekiel 31, Daniel 4, and 1 Enoch 24. ${ }^{21}$ (3) Perhaps the arboreal reversal depicted in verse 24 symbolises the collective people of Judah, once withered and dry in exile, only later to be brought into blossom back in their own land.22 Or, (4) this tender

18 Block argues that the coda of verses 22-24 supports the literary unity of the chapter and justifies reading the entire parable as pre-fall of Jerusalem. See D. Block, The Book of Ezekiel: Chapters 1-24 (NICOT; Grand Rapids, MI: Eerdmans, 1997): 549. Bernard Lang also argues that literary features of the verses indicate that the passage is an original part of chapter 17. See Bernard Lang, Kein Aufstand in Jerusalem, 65.

19 G. A. Cooke, A Critical and Exegetical Commentary on the Book of Ezekiel (ICC; Edinburgh: T\&T Clark, 1936): 191.

20 'Here it is spelled out in the language of the allegory that the kingship will be restored through the youthful ruler who was taken into exile with Ezekiel ... Regrettably, it was a future promise that did not ultimately materialize'. Ronald E. Clements, Ezekiel (Westminster Bible Companion; Louisville, KY: Westminster John Knox, 1996): 78.

21 Zimmerli, Ezekiel 1, 367.

22 Note John W. Olley's collective interpretation: 'Thus the debate becomes whether one is to interpret the 'cedar' as individual, with a royal and potentially messianic meaning (as may be suggested by the focus of the whole section on royal actions) or as collective, widening to the whole "house of Israel" (cf. v. 11) ... A collective interpretation is supported by the wider context of the book as the other references to "a high mountain" are to the place where "the house of Israel will serve me forever" $(20: 40)$, where the "sheep" will be fed by the Lord (34:14) and where Ezekiel sees the vision of the new temple and the city (40:2), that is, all eschatological and collective' 
sapling is an eschatological messianic figure associated with the restoration of Israel. ${ }^{23}$ These various answers have stemmed from differing interpretative streams over the centuries, and to some extent need not be viewed as mutually exclusive. Looking to 4QPseudoEzekiel $^{\mathrm{a}}$, the LXX, Targum Ezekiel, and The Shepherd of Hermas, the following sections will seek to establish that the fourth, messianic interpretation was prominent among early translators and interpreters.

\section{The Early 'Afterlife' of the Tree Metaphor in Ezekiel $17: 22-24$}

\section{QPseudo-Ezekiel ${ }^{a}$ (4Q385 frag. 2, lines 7-10) ${ }^{24}$}

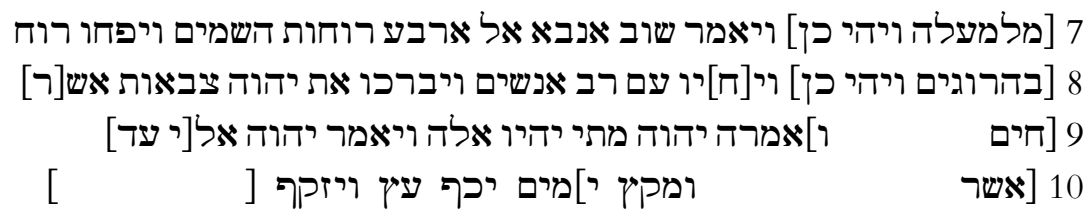

7. [from above'. And it was so.] And He said: 'Prophesy once again over the four winds of heaven and let them blow breath

8. [into the slain'. And it was so,] and a large crowd of people came [to li]fe and blessed the Lord Sebaoth wh[o]

9. [had given them life. vacat and] I said: 'O Lord! when shall these things come to be?' And the Lord said to $\mathrm{m}[\mathrm{e}:$ 'Until]

10. [after da]ys a tree shall bend and shall stand erect[ ]

4QPseudo-Ezekiel ${ }^{\mathrm{a}}$ (4Q385) is a collection of forty-eight fragments gathered from cave 4 at Qumran, dated around the First Century BC, and is closely associated with the biblical book of Ezekiel. ${ }^{25}$ Despite its fragmentary nature and textual paucity, 4Q385 has garnered quite a lot of attention over the past two decades. ${ }^{26}$ The above text reflects the

in Ezekiel: A Commentary Based on Iezekiēl in Codex Vaticanus (Septuagint Commentary Series; Leiden: Brill, 2009): 343. See also, Lust, 'And I Shall Hang Him on a Lofty Mountain', 231-50.

23 Block, Ezekiel 1-24, 551-53.

24 Text and translation from Devorah Dimant, Qumran Cave 4: XXI Parabiblical Texts, Part 4: Pseudo-Prophetic Texts (Discoveries in the Judaean Desert XXX; Oxford: Clarendon, 2001): 23-24.

25 Dimant, Qumran Cave 4, 7.

26 Monica Brady, 'Biblical Interpretation in the "Pseudo-Ezekiel" Fragments (4Q383391) from Cave Four' in Biblical Interpretation at Qumran, ed. Matthias Henze (Studies in the Dead Sea Scrolls and Related Literature; Grand Rapids, MI: Eerdmans, 2005): 88-109; Jack, 'An Arboreal Sign of the End-Time,' 337-44; George J. Brooke, 'Ezekiel in Some Qumran and New Testament Texts' in The Madrid Qumran 
final four out of the ten lines found in 4Q385 frag. 2 which depict a version of the dry bones vision recorded in Ezekiel 37:1-14. The most noteworthy difference-and the main focus at present-is line 10 , '[after da]ys a tree shall bend and shall stand erect'. These words are spoken by the Lord after the prophet asks, 'O Lord! When shall these things come to be?' enigmatically indicating that the bending and raising of a tree is to be eschatologically associated with the vision of restoration and renewal found in the dry bones vision.

Emile Puech in his article 'L'Image de l'arbre en 4QDeutéroÉzéchiel', has demonstrated that the Tree of Life interpretation provided by M. Philonenko ${ }^{27}$ is untenable. Philonenko's appeal to Isaiah 65:15-25 as a background for the text proves unsubstantial, and more importantly, 'no references have been found which include both the symbol of the tree of life and the idea of it bending and rising up'a point conceded by Alison Jack in her own argument for a Tree of Life interpretation. ${ }^{28}$ Devorah Dimant has noted the weaknesses of Jack's

Congress: Proceedings of the International Congress on the Dead Sea Scrolls, ed. Julio Trebolle Barrera and Luis Vegas Montaner (Studies on the Texts of Desert of Judah 11,1; Leiden: Brill, 1992): 322-26; É. Puech, 'L'image de l'arbre en 4QDeutéroÉzéchiel (4Q385 2, 9-10)', Revue de Qumrân 16 (1994): 429-40; M. Kister and E. Qimron, 'Observations on 4QSecond Ezekiel (4Q385 2-3)', Revue de Qumrân 15 (1992): 595-602; Matthias Henze, '4QApocryphon of Jeremiah C and 4QPseudoEzekiel: Two "Historical" Apocalypses' in Prophecy after the Prophets: The Contribution of the Dead Sea Scrolls to the Understanding of Biblical and ExtraBiblical Prophecy, ed. Kristin de Troyer and Armin Lange (Contributions to Biblical Exegesis \& Theology 52; Walpole, MA: Peeters, 2009): 25-41; Johannes Tromp, "'Can These Bones Live?" Ezekiel 37:1-14 and Eschatological Resurrection' in The Book of Ezekiel and Its Influence, 70-76; Albert L. A. Hogeterp, Expectations of the End: A Comparative Traditio-Historical Study of Eschatological, Apocalyptic and Messianic Ideas in the Dead Sea Scrolls and the New Testament (Studies of the Texts of the Desert of Judah 83; Boston: Brill, 2009): 269-75; Richard Bauckham, 'A Quotation from 4QSecond Ezekiel in the Apocalypse of Peter', Revue de Qumrân 15 (1991): 437-46; Benjamin G. Wright, 'Qumran Pseudepigrapha in Early Christianity: Is 1 Clem. 50:4 a Citation of 4QPseudo-Ezekiel (4Q385)?' in Pseudepigraphic Perspectives: The Apocrypha and Pseudepigrapha in Light of the Dead Sea Scrolls: Proceedings of the International Symposium of the Orion Center for the Study of the Dead Sea Scrolls and Associated Literature, 12-14 January 1997, ed. Esther G. Chazon and Michael Stone (Studies on the Texts of the Desert of Judah 31; Boston: Brill, 1999): 183-93; F. García Martínez, 'The Apocalyptic Interpretation of Ezekiel in the Dead Sea Scrolls' in Interpreting Translation: Studies on the LXX and Ezekiel in Honour of Johan Lust, ed. F. García Martínez and M. Vervenne (Bibliotheca ephemeridum theologicarum lovaniensium 192; Leuven: Leuven University PressPeeters, 2005): 163-76.

27 Philonenko, 'Un arbre se courbera et se redressera (4Q385 29-10)', 401-404, argues that the Tree of Life is intended to point to resurrection.

28 Jack, 'An Arboreal Sign of the End-Time', 344. 
argument from the creation narrative in Genesis 2 stating, 'PsEzek's references are taken from the creation story in Genesis 1 and not from the Paradise Story in Genesis 2 ... What's more, the Tree of Life would have been designated as a specific tree העיץ, "the tree", and not just עי, "a tree", as is the case here. ${ }^{29}$ Consequently, reading the tree symbol in 4Q385 as referring to the Tree of Life, whether grounded in the prophets or the creation narratives, proves unconvincing.

Both Puech and Dimant recognise that line 10 could be an allusion to the tree spoken of in Ezekiel 17:24. Puech writes:

Si le rameau en Éz 17, 22 ss vise le rejeton davidique des temps messianiques, la métaphore de Deutéro-Ézéchiel n'est pas suffisamment bien conservée pour se prononcer à ce sujet. Toutefois, l'arbre peut englober et le rameau messianique et le reste juste duquel il sortira, qui d'humilié revivra à nouveau sur la terre d'Israël, à Jerusalem même, à la suite du «comment» illustré par la vision des ossements desséchés. ${ }^{30}$

Given the brevity of line 10, Puech's conservatism can be appreciated. It is interesting, however, that he boldly goes on to interpret this single line as a 'replacement' of 37:11-14, leading to the conclusion that the tree represents the community of the faithful awaiting a messiah. Dimant also argues that Puech's position is 'conjectural' and that while possibly referring to Ezekiel 17:24, the tree may 'stand as a symbol for death and resurrection'. ${ }^{31}$

If one reads line 10 of 4Q385 frag. 2 in light of Ezekiel 17:22-24, the tree 'that shall bend and stand erect' could possibly refer to a restored Davidic monarchy. ${ }^{32}$ This is quite plausible given other

29 Dimant, DJD XXX, 29.

30 'If the branch in Ez 17.22ff. is the Davidic offspring of messianic times, the metaphor of Deutero-Ezekiel is not sufficiently well preserved to rule on this subject. However, the tree may include the messianic branch and the righteous remnant coming out that will revive again the humbled land of Israel and also to Jerusalem, with the sequence of "how" illustrated by the vision of the dry bones.' Puech, 'L'Image de l'arbre', 438.

31 Dimant, DJD XXX, 29.

32 As scholars noted, The Epistle of Barnabas 12.1 offers an early christological

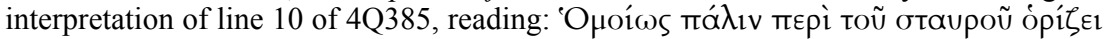

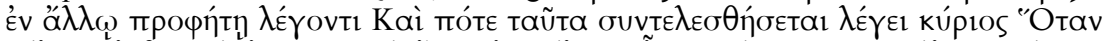

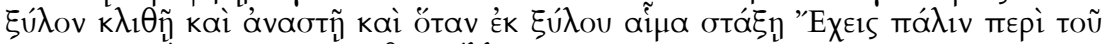

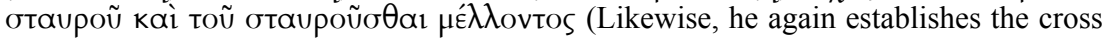
in another prophet who says, "And when will these things be fulfilled?" [And] the Lord says, "Whenever a tree shall be bent down and raised up and whenever blood shall drip from a tree." There again is a future promise concerning the cross and the one who would be crucified.' [Greek text taken from J. B. Lightfoot, Apostolic Fathers, BibleWorks 9. Translation is original to the author]). The use of $\xi u ̛ \lambda$ ou ties 
prophetic references to the future of the Davidic line using treelanguage (Isa. 11:1; Jer. 23:5; Zech. 3:8; 6:12), and the further development of a future king in Ezekiel 37:22-24, which reads: 'And I will make them one nation in the land, on the mountains of Israel. And one king shall be king over them all ... My servant David shall be king over them, and they shall have one shepherd. ${ }^{33}$ As rewritten biblical text, 4Q385 could be a conflation of the image portrayed in Ezekiel 17:22-24 and the 'tree' (עין) imagery of chapter 37. The Davidic line, once brought low through YHWH's judgement and exile, would eschatologically rise alongside the restored people of God. Johannes Tromp notes regarding 4Q385 frag. 2, 'The motif of hastening time is undoubtedly an innovation as compared to the biblical text, and changes its original intention by turning the restoration promised by the vision of the dry bones into an eschatological event.' ${ }^{34}$ The proposed reading would also allow the most straightforward reading of the singular עי, 'a tree' in line 10.35

\subsection{Ezekiel 17:22-24: $L X X^{36}$}

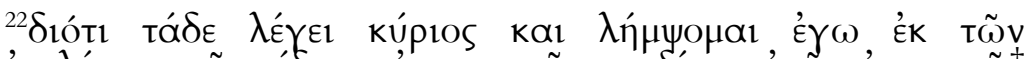

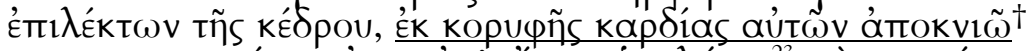

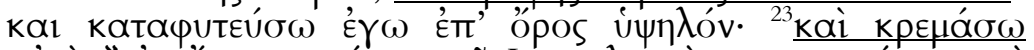

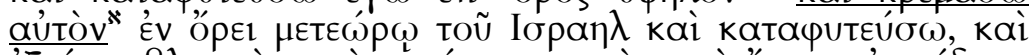

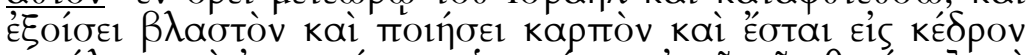

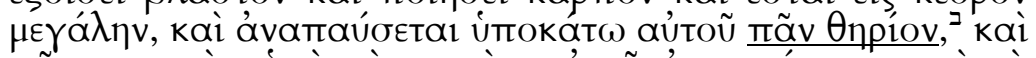

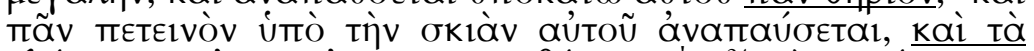

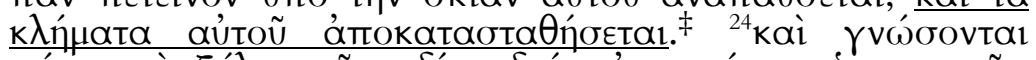

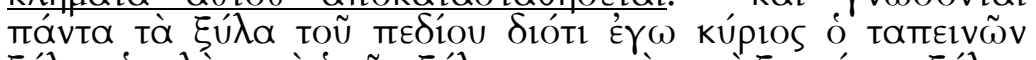

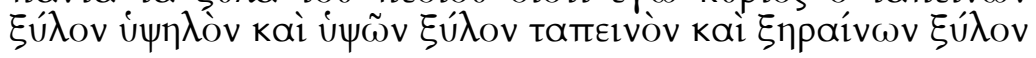

both texts more closely to the LXX translation of Ezek. 17:22-24 instead of Ezek. 37:16-20. See Jack, 'An Arboreal Sign of the End-Time', 341; Menahem Kister, 'Barnabas 12:1; 4:3 and 4QEzekiel', Revue Biblique 97 (1990): 63-67.

33 It is perhaps possible that the tree reference in 4 Q 385 is solely alluding to the one piece of wood (עיץ אדר) discussed in Ezek. 37:16ff. However, the description of the piece of wood in chapter 37 does not appear to fit with the 'bending and standing' portrayal given in 4Q385.

34 Tromp, Expectations of the End, 72.

35 It must be conceded that $4 \mathrm{Q} 385$ frag. 2 is a very brief text and all conclusions must be held loosely. However, the proposal made here is strengthened I believe by the LXX and Targum interpretations.

36 Joseph Ziegler, ed., Ezechiel (Septuaginta: Vetus Testamentum Graecum; Auctoritate Academiae Scientiarum Gottingensis editum, 16.1.3; Göttingen: Vandenhoeck \& Ruprecht, 2006): 162. 


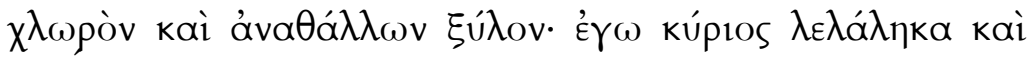
$\pi 01 \eta \sigma \omega$.

$\dagger$ 'from the top of their heart I will nip off'; " 'and I will hang it/him';

I 'every animal'; ; 'and its branches shall be restored'

Johan Lust has illustrated with regard to these verses that the LXX translation is highly literal, thereby exacerbating the differences. ${ }^{37}$ Lust devotes much of his attention to the first two deviations underlined above, arguing that such changes support his thesis that 'in most cases, the LXX does not add to the messianic character of those texts which are traditionally seen as proclamations of the coming of an individual royal, prophetic, or priestly messiah who will definitely establish the Lord's kingdom on earth' ${ }^{38}$ Lust asserts that the Old Greek (OG) of the LXX is best represented by papyrus 967 (P967) which differs slightly in this text from Codex Vaticanus (B) and Codex Alexandrinus (A) in two primary ways. ${ }^{39}$

First, P967 renders the Hebrew hapax ותלול at the end of verse 22 as крєнабтóv (adjective, 'high') with no indication of a pronoun,

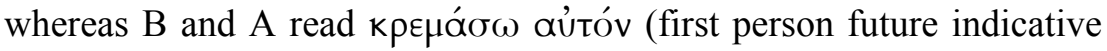
plus pronoun, 'I will hang it/him'). Secondly, P967 includes a plural

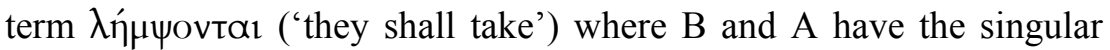

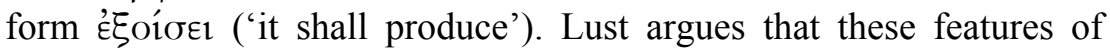
P967 demonstrate that 'The OG is less open to an individual messianic

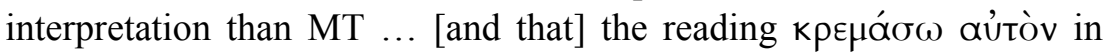
the majority of the manuscripts is probably due to a Christian reworking of the text.' 40

37 Lust, 'And I Shall Hang Him on a Lofty Mountain', 238.

38 Lust, 'And I Shall Hang Him on a Lofty Mountain', 231.

39 However, as Hector Patmore has recently pointed out, the textual deposits of Ezekiel found at Masada and Qumran appear to point toward two Vorlagen separately undergirding the MT and OG of P967. We can follow Lust's argument regarding P967 as reflecting a distinct version of the text, but 'unless new materials come to light, there is no credible way of establishing the historical precedence or originality of either' the MT or the OG tradition (p. 242). See Hector M. Patmore, 'The Shorter and Longer Texts of Ezekiel: The Implications of the Manuscript Finds from Masada and Qumran', Journal for the Study of the Old Testament 32.2 (2007): 231-42; Ingrid E. Lilly, Two Books of Ezekiel: Papyrus 967 and the Masoretic Text as Variant Literary Editions (VTSup 150; Leiden: Brill, 2012).

40 Lust, 'And I Shall Hang Him on a Lofty Mountain', 250. Olley notes that any explicit Christian reference to this text is 'comparatively late'. See, Olley, Ezekiel, 342. 


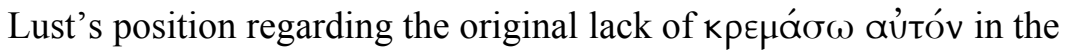
OG is rather convincing. ${ }^{41}$ However, his overall collective reading of the passage is not. Despite Lust's collective reading, kapdias is singular and the plural genitive following it finds a natural antecedent

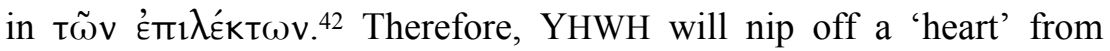
among the plural 'choice ones', likely referring to the cedar. Given this understanding, the cedar symbolises the nation collectively or a faithful post-exilic remnant, and the 'heart' selected from this group is to become a new divinely established Davidic monarch. The LXX omission of רך does not appear as significant as Block has argued. ${ }^{43}$ It is possible that the LXX interpreted the seemingly redundant phrase 'tender sapling' as kapoías in an effort to simply communicate the 'middle, midst, centre ... [or] heart (of a tree)' without making a significant theological excision. ${ }^{44}$

Lust's argument that the singular form $\mathfrak{E}^{\xi} \mathrm{oí}_{\sigma \in 1}$ is unoriginal and should be replaced by the P967 reading $\lambda \hat{n} \mu \psi$ ovtaı is unconvincing. ${ }^{45}$ The latter could have easily arisen out of an effort to continue the use of $\lambda \alpha \mu \beta a ́ v \omega($ cf. 17:3, 22) and thereby harmonise the undisputed lexical parallels between verses 3-4 and verse 22.46 Again, if Lust's position is conceded, there is still a severe tension in that the plural

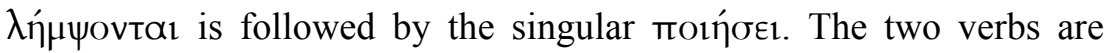
undoubtedly referring to the same subject, and the fact that every other verb ending and pronoun in verse 23 is singular makes Lust's collective reading difficult. If this proposal is correct, then the singular tree-monarch of verse 22 will grow into a majestic tree that will send out branches, produce fruit, provide shade and rest to both bird and

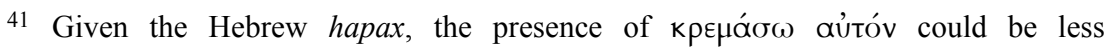
intentional than Lust asserts.

42 The Peshitta follows the LXX's reading of 'heart'. In square script the Syriac reads: ומן רישה אקטום לבה ('and from its top I will lop off its heart'). Emanuel Tov notes that some scholars believe the Peshitta relies heavily on the LXX as a source for lexical information (E. Tov, Textual Criticism of the Hebrew Bible [3rd edn; Minneapolis: Fortress, 2012]: 152). Therefore, it is probable that the Peshitta relied on the LXX in translating ינקותיו רך, and consequently, does not offer a true variant reading.

43 Block, Ezekiel 1-24, 550 n. 145.

44 J. Lust, E. Eynikel, and K. Hauspie, A Greek-English Lexicon of the Septuagint: Part II $K-\Omega$ (Stuttgart: Deutsche Bibelgesellschaft, 1996): 228.

45 It is, however, not uncommon for נשיא to be translated by a form of $\lambda \alpha \mu \beta \alpha ́ v \omega$.

46 Lust, 'And I Shall Hang Him on a Lofty Tree', 239. 


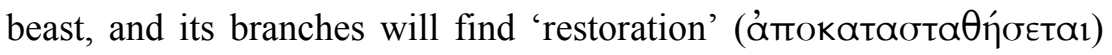
beneath its height. ${ }^{47}$

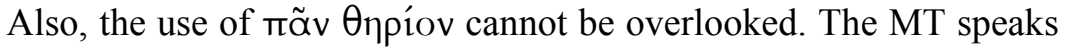
specifically about birds, while the LXX extends the shade and shelter to the animal kingdom. This seems to indicate that early in the interpretative history of verse 23 , readers were associating this tree with those symbolic images of Ezekiel 31:6 and Daniel 4:12. However, John Olley points out that B, P967, and Origen read ópveov ('bird') whereas A, which is followed by Joseph Ziegler in the above text, reads $\theta$ npíov.

In his commentaryon the B text of Ezekiel, Olley puts forward an interesting question regarding an individual, royal reading of B: 'Could it be that the person(s) responsible for B were the first to so interpret this passage [in a messianic fashion]?'48 In asking this question, he allows the possibility that B offers a distinct interpretative stratum, one which very well could be the 'first' representative of a messianic reading of Ezekiel 17:22-24. Whether or not B is the first, Olley finds it difficult to ignore the messianic overtones of the Greek text. Therefore, P967, and certainly B, offer translations of Ezekiel 17:22-24 that are by no means anti-individual, and perhaps even lend support to an individual, royal interpretation with messianic potential.

\subsection{Ezekiel 17:22-24: The Targum ${ }^{49}$}

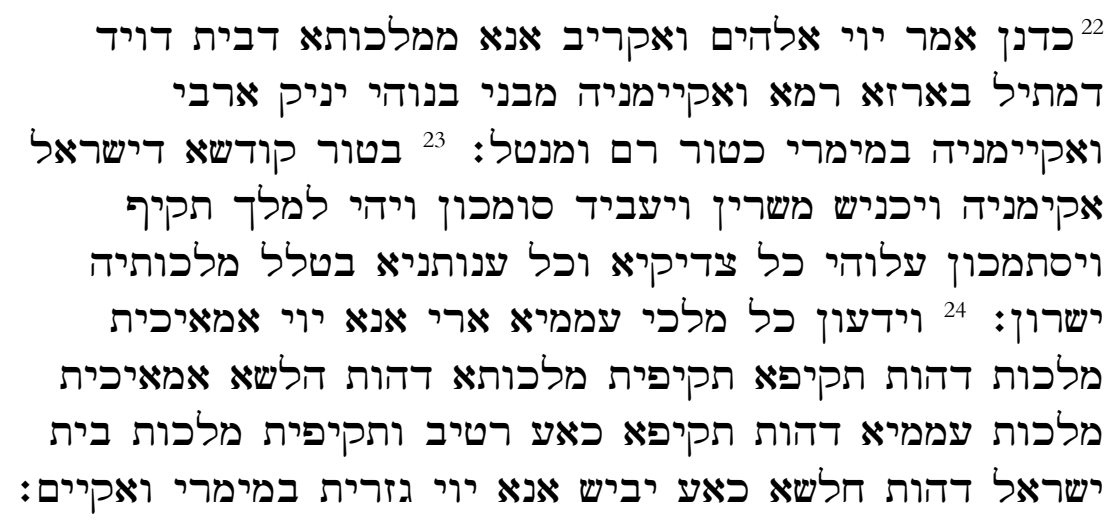

47 Nowhere else in chapter 17 is the symbol of a tree used to refer to a collective group.

48 Olley, Ezekiel, 342.

49 Alexander Sperber, The Latter Prophets According to Targum Jonathan (vol. 3 of The Bible in Aramaic; Leiden: Brill, 1962): 300-301. 
${ }^{22}$ Thus says the Lord God, 'I Myself will bring near a child from the kingdom of the house of David which is likened to the lofty cedar, and I will establish him from among his children's children; I will anoint and establish him by My Memra on a high and exalted mountain. ${ }^{23}$ On the holy mountain of Israel will I establish him, and he shall gather together armies and build fortresses and become a mighty king; and all the righteous shall rely upon him, and all the humble shall dwell in the shade of his kingdom. ${ }^{24}$ And all the kings of the nations shall know that I the Lord have humbled the kingdom which was mighty and have made mighty the kingdom which was weak. I have humbled the kingdom of the nations which was mighty as a green tree, and have made mighty the kingdom of the House of Israel, which had been as weak as a dried-up tree. I the Lord, have decreed it by My Memra and I will fulfill it. ${ }^{50}$

Targum Ezekiel provides an exceedingly clear example of an individual, royal reading of Ezekiel 17:22-24. As to be expected with targumic interpretation, the symbols are interpreted for the reader and then the object symbolised is inserted into the text. ${ }^{51}$ So, in verse 22 the extensive commentary interprets the tender sapling of the MT as 'a child from the kingdom of the house of David'.52 Given such commentary, Samson Levey's proposal that Targum Ezekiel prefers merkabah mysticism over against messianic activism appears unsustainable. Levey is correct in pointing out that one does not encounter the term mešiha', and as Levey notes, 'There were historical interludes in Palestine under Roman rule when Messianic activism, or even articulation, carried the death penalty with it. ${ }^{53}$ However, in the above text, the cedar tree clearly represents a Davidic heir who will 'gather armies', 'build fortresses', and 'become a mighty king'. Such

50 Samson H. Levey, The Targum of Ezekiel: Translated with a Critical Introduction, Apparatus, and Notes (vol. 13 of The Aramaic Bible; Wilmington, DE: Michael Glazier, 1987): 56-57. Dating Targum Jonathan is notoriously difficult given its complex transmission history, however Philip S. Alexander notes: 'The practice of translating the books of the Bible into Aramaic began in the Second Temple period ... Moreover, given their dialect, it is highly unlikely that Onk [Targum Onkelos] and Yon [Targum Jonathan] (at least as to their basic texts) could have originated after 135 CE.' See, Philip S. Alexander, 'Jewish Aramaic Translations of Hebrew Scriptures' in Mikra: Text, Translation, Reading and Interpretation of the Hebrew Bible in Ancient Judaism and Early Christianity, ed. M. J. Mulder and H. Sysling (Minneapolis: Fortress, 1990): 247.

51 See Alberdina Houtman and Harry Sysling, Alternative Targum Traditions: The Use of Variant Readings for the Study in Origin and History of Targum Jonathan (Studies in Aramaic Interpretation of Scripture 9; Leiden: Brill, 2009): 15-39.

52 While Block affirms a messianic interpretation of the MT of this passage, it is somewhat puzzling how Block refers to this statement as 'subdued paraphrase'. See Block, Ezekiel 1-24, 550 n. 145.

53 Levey, The Targum of Ezekiel, 5. 
language does not prove overly effective in disguising the overt sense of messianism in this passage. Similarly, Alinda Damsma has recently concluded regarding this text:

[A]lthough Targum Ezekiel does not explicitly mention the Messiah, in vss. 23-24 it equips the God-given might ruler of Davidic lineage with armies and fortresses, speaks of the righteous and the humble who shall linger in his presence, and envisages the downfall of the once mighty kingdom. Hence, according to Kimhi's commentary on Ezek. 17:24, this rendering in Targum Ezekiel does seem to refer to the Messiah. ${ }^{54}$

The Targum appears to interpret the text within a literal, prophecyfulfilment pattern that indicates a contemporary desire for national leadership.

Aside from assigning a militaristic, Davidic monarch to the cedar image, the Targum also associates the other trees of the passage with the 'kings of the nations'. In verse 24, the MT reads that 'all the trees of the field shall know that I am YHWH'. Interestingly the Targum does not interpret these trees to be nations, but rather as individual kings of nations. Just as an individual Davidic monarch was represented by the cedar sapling, the kings of the nations are identified as trees as well.

Targum Ezekiel does not give any indication of concern for Tree of Life imagery or collectiveness within its interpretation of the text. The picture of rest and shelter in verse 23, which often draws up such associations, is ironically interpreted as an individual's collection of weapons of war needed to establish his political kingdom.

\subsection{The Shepherd of Hermas 67:1; 69:1-255}

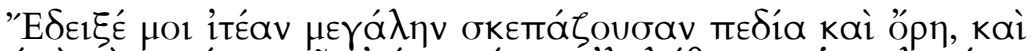

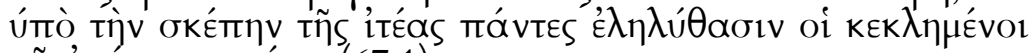

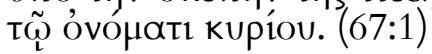

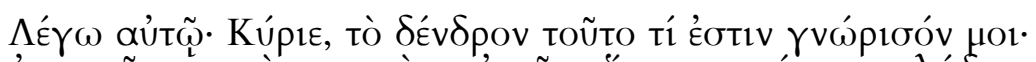

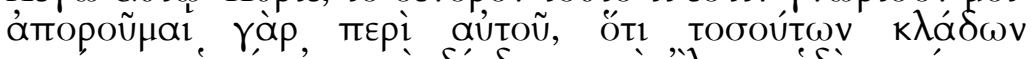

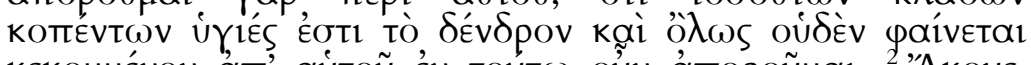

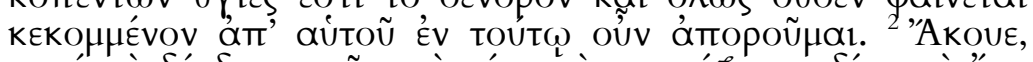

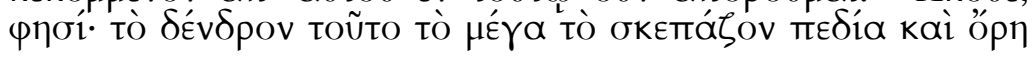

54 A. Damsma, 'The Merkabah as a Substitute for Messianism in Targum Ezekiel?', VT 62 (2012): 7.

55 Text and translation from Michael Holmes, ed., The Apostolic Fathers: Greek Texts and English Translations (3rd edn; Grand Rapids, MI: Baker Academic, 2007): 597, 603. 


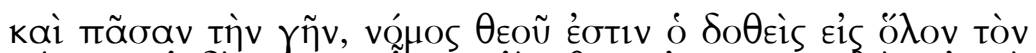

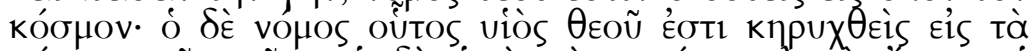

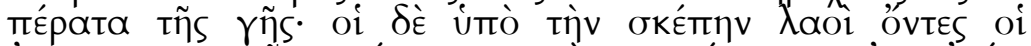

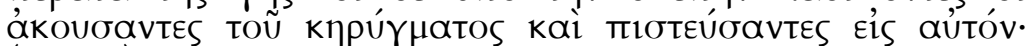
$(69: 1-2)$

He showed me a great willow tree that overshadowed the plains and mountains, and all who are called by the name of the Lord came under the shade of the willow. (67:1)

I said to him, 'Sir, tell me what this tree means, for I am perplexed about it, because even though so many branches were lopped off, the tree is healthy, and nothing appears to have been lopped off from it; consequently, I am perplexed.' 2 'Listen,' he said. 'This great tree, which overshadows plains and mountains and all the earth, is the law of God, which is given to the whole world, and this law is the Son of God, who has been proclaimed to the ends of the earth. And the people who are under the shadow are those who have heard the preaching and believed in him. (69:1-2)

$\mathrm{SH}$ is an early text that dates from the mid to late Second Century $\mathrm{AD}^{56}$ and was viewed favourably by both Irenaeus and Clement. ${ }^{57}$ It presents a strongly christological and messianic allusion to Ezekiel 17:22-24. Interestingly, the latter part of the book is divided into ten 'parables' (Gr. mapaßoג'́, Heb. משל ), the same term used to announce the prophetic parable in Ezekiel 17. The eighth parable, from which the above passages are taken, addresses concerns about penitence and repentance for confessing believers who have committed apostasy or fallen away. In this parable $\mathrm{SH}$ shows familiarity with the entirety of Ezekiel's parabolic vision. The image of the willow tree is likely derived from the reference made in Ezekiel 17:5: 'by abundant waters he placed a willow tree' (על-מים רבים צפצפה שמו). However, the 'cosmic tree' description of the willow in 67:1 as 'overshadow[ing] plains and mountains and all the earth', strongly reflects Ezekiel's portrayal of the mighty cedar described in 17:23.

The parable begins with the Shepherd cutting off branches and giving them to those under the shade of the great willow tree, and these branches will be returned and examined by the Shepherd to determine the spiritual condition of the people. In the course of the cutting,

56 David Hellholm, 'The Shepherd of Hermas' in The Apostolic Fathers: An Introduction, ed. Wilhelm Pratscher (Waco: Baylor, 2010): 238. It is unfortunate that Hellholm overlooks the present discussion in his section on intertextual relationships within $S H$.

57 Joseph Verheyden, 'The Shepherd of Hermas', Expository Times 117 no. 10 (2006): 397. 
Hermas asks the Shepherd about this great tree, and the reply is that the tree is 'the law of God, which is given to the whole world, and this law is the Son of God, who has been proclaimed to the ends of the earth' (69:2). Verse 3 goes on to say that all of those under the shade of the tree are Christian believers, which perhaps provides a christological interpretation of the divine purpose statement given in Ezekiel 17:24: 'And all the trees of the field shall know that I am YHWH'. The branches given to the believers represent a portion of the law of God, which is fulfilled in Jesus, and the universal applicability of law is made possible by the universal proclamation of the Son of God. The world was given the law_instead of simply Israel—because the Son of God was given to the world.

\section{Conclusion}

It is evident in the above analysis that interpretation is required in studying any history of interpretation. However, given the interpretative trajectories of the above source, especially the nonChristian sources 4QPseudo-Ezekiel ${ }^{\mathrm{a}}$, the LXX, and the Targum of Ezekiel, it is not outside the scope of reason to conclude that political and messianic notions were likely being associated with the tree symbolism of Ezekiel 17:22-24 relatively early in the text's history. Messianism in the transmission history of Ezekiel is questioned by some and remains an important issue that demands careful study. ${ }^{58}$ While it is not the point of this study to try to make the case from one text, the early history of interpretation of Ezekiel 17:22-24 opens the possibility that early interpreters were reading this tree metaphor as a politically charged symbol of kingship associated with natural and national restoration, and not exclusively as a reference to a collective people or the Tree of Life. ${ }^{59}$ Verse 23 draws upon the image of a cosmic tree, but even this imagery cannot be divorced from its political associations. The cosmic tree represents the Davidic ruler himself, along with the dominion of divine order he would establish. From the

58 J. Lust, 'Messianism in LXX-Ezekiel: Towards a Synthesis', in The Septuagint and Messianism, ed. M. Knibb (BETL 195; Leuven, 2006): 417-30.

59 Anthony R. Petterson has recently argued a similar thesis in relation to the Book of the Twelve. See A. R. Petterson, 'The Shape of the Davidic Hope across the Book of the Twelve', JSOT 35 (2010): 225-46. He writes: '[T] he Twelve presents a consistent and robust hope for a future Davidic king who is central to Yahweh's restoration purposes' (226). 
eschatological allusion of a humbled yet restored monarchy at Qumran to the militaristic hopes of early Judaism, this arboreal prophecy beautifully portrays the future hopes of a righteous remnant longing for YHWH to establish his king and kingdom - a topic the New Testament speaks to quite extensively. 